(1) Fatma Gül Yurdakul,

(1) Aslı Çalışkan Uçkun,

(1) Hatice Bodur,

(1) Nevzat Mehmet Mutlu,

(1) Özlem Balkız Soyal,

(D) Işıl Özkoçak Turan

\section{Intensive Care Unit-acquired Paresis: Risk Factors in Conscious and Cooperative Patients in Intensive Care Units}

\author{
Yoğun Bakım Ünitesinde Kazanılmış Parezi: Yoğun \\ Bakım Ünitesinde Bilinci Açık ve Koopere Hastalarda \\ Risk Faktörleri
}

Received/Geliş Tarihi : 12.09.2018 Accepted/Kabul Tarihi : 08.01.2019

${ }^{\circ}$ Copyright 2019 by Turkish Society of Intensive Care Turkish Journal of Intensive Care published by Galenos Publishing House.
Fatma Gül Yurdakul, Aslı Çalıșkan Uçkun, Hatice Bodur

Ankara Numune Training and Research Hospital,

Clinic of Physical Medicine and Rehabilitation, Ankara, Turkey

Nevzat Mehmet Mutlu, Özlem Balkı Soyal, Ișl Özkoçak Turan

Ankara Numune Training and Research Hospital, Clinic of Anesthesiology and Reanimation, Ankara, Turkey

Fatma Gül Yurdakul MD (四),

Ankara Numune Training and Research Hospital,

Clinic of Physical Medicine and Rehabilitation, Ankara, Turkey

E-mail : fatmagulonder@gmail.com

Phone : : +90 5059254214

ORCID ID : orcid.org/0000-0001-8630-9233
ABSTRACT Objective: The aim of this study was to identify the frequency of intensive care unitacquired paresis (ICU-AP) and predisposing factors for muscle weakness in our ICU patients. Materials and Methods: A prospective observational study was conducted in a 25-bed ICU of a tertiary hospital. Patients who were cooperated with muscle strength examination, stayed in ICU more than three days and had no preexisting neuromuscular disorder were included in the study. The diagnosis of hospitalization, need for mechanical ventilation, comorbidities, length of ICU stay, mobilization level, discharge status, and Sequential Organ Failure Assessment (SOFA) were recorded. Manual muscle strength test was assessed according to Medical Research Council scale. Handgrip and finger pinch strength values were recorded.

Results: Forty-two patients completed muscle strength examination. ICU-AP was determined in $16(38.09 \%)$ patients. Length of ICU stay, mechanical ventilation rate, SOFA score and frequency of decubitus ulcers were higher in patients with ICU-AP $(p<0.05)$. There was a significant relationship only between mechanical ventilation and ICU-AP

Conclusion: ICU-AP is a common problem in critically ill patients and influences outcomes of patients. Patients without mechanical ventilation may develop ICU-AP and mechanical ventilation can be determined as one of the risk factors for muscle weakness.

Keywords: Intensive care, mechanical ventilation, polyneuropathies

ÖZ Amaç: Çalışmamızın amacı yoğun bakım ünitesindeki (YBÜ) hastalarımızda, kazanıımış parezi (KP) sıklı̆ı̆ını ve kas güçsüzlüğü için predispozan faktörleri belirlemektir.

Gereç ve Yöntem: Üçüncü basamak bir hastanenin 25 yataklı YBÜ'de prospektif gözlemsel bir çalışma yürütülmüştür. Kas gücü muayenesine koopere olan, YBÜ'de kalışı üç günden fazla olan ve daha öncesinde nöromüsküler bozukluğu olmayan hastalar dahil edildi. Yatış tanısı, mekanik ventilasyon intiyacı, komorbiditeleri, yatıș süresi, mobilizasyon düzeyi, taburculuk durumu, Organ Yetmezliği Değerlendirmesi (SOFA) kaydedildi. Manuel kas gücü testi Medical Research Council ölçeğine göre değerlendirildi. Kaba kavrama ve üçlü kavrama ölçüleri yapıldı.

Bulgular: Kırk iki hasta kas gücü muayenesini tamamladı. YBÜ-KP 16 hastada $(\% 38,09)$ saptandı. YBÜ'de yatış süresi, mekanik ventilasyon oranı, SOFA skoru ve dekübit ülser sıklı̆ı YBÜ-KP olan hastalarda daha fazla idi $(p<0,05)$. Mekanik ventilasyon ve YBÜ-KP arasında anlamlı ilişki bulundu. Sonuç: YBÜ-KP yoğun bakım hastalarında sık görülen bir problemdir ve hastaların son durumlarını etkilemektedir. Mekanik ventilasyona bağlı olmayan hastalarda da YBÜ-KP görülebilmektedir ve mekanik ventilasyon kas güçsüzlüğü için risk faktörlerinden biri olarak tanımlanabilir.

Anahtar Kelimeler: Yoğun bakım, mekanik ventilasyon, polinöropatiler 


\section{Introduction}

Neuromuscular damage is an unexceptional complication in intensive care units (ICU). Patients in ICU may develop extensive muscle weakness, diffuse muscle atrophy, and decrease in deep tendon reflexes. Severe muscle weakness in these patients is named as ICU-acquired paresis (ICU-AP), ICU-acquired weakness or critical illness polyneuromyopathy (1-3). It is known that this syndrome is related with an increase in the length of hospitalization and mortality (1).

The methods used for ICU-AP diagnosis are related to the level of consciousness of the patient. Medical Research Council (MRC) sum-score was identified for to test the muscle strength in co-operative patients (4). It is not possible to examine the muscle strength in unconscious patients. In early phase of critical illness, electrophysiological tests may be helpful by excluding other factors (demyelination disorders) for weakness and muscle biopsy can support the muscle involvement (5).

In recent years ICU-AP associated risk factors have been determined as multiple organ failure, sepsis, severity of illness, hyperglycemia, and duration of ICU stay, parenteral nutrition, red blood cell transfusion, receiving vasopressor and catecholamines $(1,5)$. Hermans et al. (5) indicated that reports about the effect of corticosteroids and neuromuscular blocking agents were inconsistent. Although former studies showed a relation with ICU paresis and corticosteroid use, current prospective studies did not find a primary relationship between ICU paresis and the use of corticosteroid and neuromuscular blocking agents.

The incidence of ICU paresis has been reported from $30 \%$ to $50 \%$, depending on the time of diagnosis, the severity and the etiology of the illness (6).

Although there are studies investigating weakness in intensive care patients, predisposing and preventive factors in the literature, to our knowledge there is no study about ICU paresis in our country. Our aim is to identify the ICU-AP rates and predisposing factors for muscle weakness in our ICU patients.

\section{Materials and Methods}

Our study protocol was approved by the Ankara Numune Training and Research Hospital Clinical Researches Local Ethics Committee with the decision no 1314-2017, approval date 29.03.2017 and written informed consent was obtained from all the patients or patients' first degree relatives.
A prospective observational study was conducted in a 25-bed tertiary hospital ICU between April 2017 and May 2018. All of the conscious patients admitted to ICU in this period were evaluated. Exclusion criteria were: younger than 18 years old, preexisting any central or peripheral nervous system disorder or muscular disease, traumas that prevent muscle strength examination and cause diffuse tissue loss (extensive burns, etc), pregnancy, no cooperative with the muscle strength examination and stay in ICU less than three days.

Ramsey Sedation scale that is the most commonly used scale for consciousness level of patients were calculated for each patient (7). The patients with Ramsey score 2 or 3 (indicates the patients who are cooperative, oriented, tranquil and responsive to commands only) were included in the study.

Age, gender, ICU admission diagnosis, mechanical ventilation requirement, co-morbidities, length of ICU hospitalization, mobilization level, total parenteral nutrition, decubitis ulcers and discharge status were evaluated. Body temperature, complete blood count, routine biochemical tests, C-reactive protein levels, and phosphor levels, cardiac and pulmonary parameters, were recorded. The Sequential Organ Failure Assessment (SOFA) was used to evaluate the disease severity and morbidity. The six organ systems (respiratory, cardiovascular, central nervous system, renal, coagulation and liver) are assessed as having a total score of 6-24 with SOFA score (8). Laboratory assessments and SOFA score were evaluated at ICU admission.

Adequate assistance was supplied to patients for mobilization. Mobilization activities were recorded at 3 levels: 1) Sitting with hanging legs at the edge of the bed for 3 minutes; 2) Transferring from bed to chair and sitting in the chair for 3 minutes; 3) Walking 10 meters.

Patients had detailed neurological examination by a single physician and manual muscle force testing was assessed according to MRC scale. This scale involves both upper and lower limbs including 12 muscle groups. Total score ranges 0 to 60 (each muscle group score changes between 0 and 5). A patient with a MRC sum score less than 48 was accepted she/he had clinically weakness $(9,10)$.

Grip strength (kilograms) of hands was measured by Jamar dynamometer. During the evaluation the shoulder was in adduction and neutral rotation, the elbow was in $90^{\circ}$ flexion, the wrist in the neutral position. In the examination three measurements were made with a minute interval 
between each measurement for hand grip strength and averages were recorded (11).

Finger dynamometer (Baseline ${ }^{\circledR}$ hydroulic pinch gauge) was used for testing finger pinch strength. During the measurement shoulder was placed in the adduction, the elbow in the $90^{\circ}$ flexion, the forearm in the neutral position and the wrist in the $20-30^{\circ}$ extension. The finger pinch was repeated 3 times and the mean value was recorded.

Manual muscle strength test, grip and finger pinch strength examination were performed by same physician. A total MRC score less than 48 or handgrip less than $11 \mathrm{~kg}$ for males/7 $\mathrm{kg}$ for females were accepted as ICU-AP (12). Demographic and clinical variables were assessed in patients with and without paresis.

\section{Statistical Analysis}

Statistical analyses were performed with Statistical Package for Social Sciences for Windows 20 package program. Shapiro-Wilk test was used to test for normality; the results of this test indicated that age SOFA score and muscle strength score were normally distributed. Non-parametric tests were used because of the unbalanced patient groups. Mean, median minimum, maximum and standard deviation values were used for the general descriptive statistics for continuous variables. When analyzing the differences of the continuous variables between the two groups Mann-Whitney $U$ test was used. The differences between categorical variables were determined using chi-square or Fisher's exact tests. While studying the relations between the MRC score, handgrip and finger pinch strength Spearman correlation tests were used. Binary logistic regression analysis was used to examine the association with paresis and risk factors. The threshold for statistical significance was set at $p<0.05$.

\section{Results}

A total of 805 patients had been admitted to our ICU in the study period. Of these patients 143 were conscious and 42 patients completed the muscle strength examination (Figure 1). The median of stay in ICU was 17 days and after the onset of mechanical ventilation was 17 days (range, 6-54 days and 4-54 days respectively). Most frequently diagnosis at admission to ICU among the evaluated patients was airway and breathing problems (21 patients had infectious or noninfectious dyspnea) and the other diagnosis were terminal cancer, trauma, myocardial infarction, renal failure, pericarditis, serious infections and gastrointestinal bleeding.
ICU-AP was determined in 16 (38.09\%) patients according to MRC score. Besides we found 15 patients handgrip less than $11 \mathrm{~kg}$ and $7 \mathrm{~kg}$ (for males and females respectively). Handgrip strength of one patient was higher than $11 \mathrm{~kg}$ although he had a MRC scale score less than 48 . He had more severe muscle weakness in lower extremities. Our analyses were performed with the ICU-AP groups that were formed by considering the MRC scale. Length of ICU stay, mechanical ventilation rate, SOFA score, total parenteral nutrition and decubitis ulcers were higher in patients with ICU-AP $(p<0.05)$. Patients' demographic and clinic characteristics according to ICU-AP were described in Table 1.

The mean value for muscle strength test score was $48.85 \pm 11.13$ (24-60); handgrip strength was 15.41 \pm 11.40 (142.50) and finger pinch strength was 3.99 2.65 (0.50-9.50). There was a high degree correlation with muscle strength, handgrip and finger pinch strength ( $p<0.001$ and $r>0.6) .29$ of our patients were mobilized during the ICU stay. Eleven patients $(68.75 \%)$ with ICU-AP were not mobilized. Patients' discharge status was recorded. While the rate of discharge to home was $6.25 \%$ in patients with ICU-AP, this rate was $30.6 \%$ for the patients with no muscle weakness (Table 2).

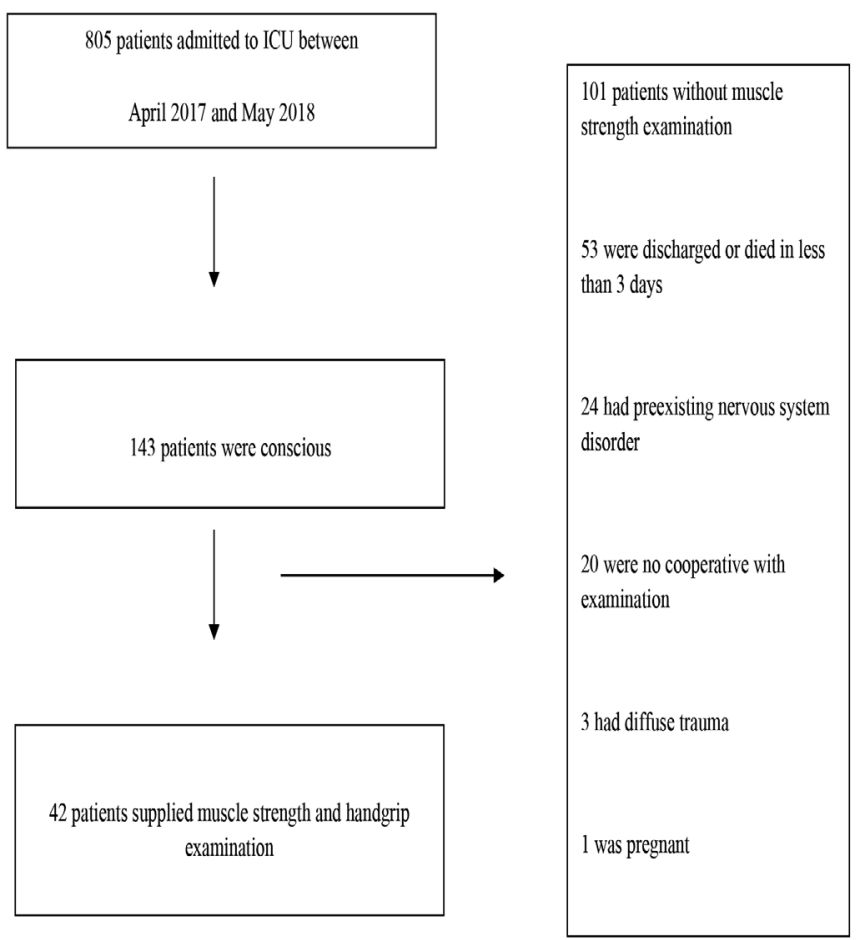

Figure 1. Diagram of intensive care units patients' assessment ICU: Intensive care units 


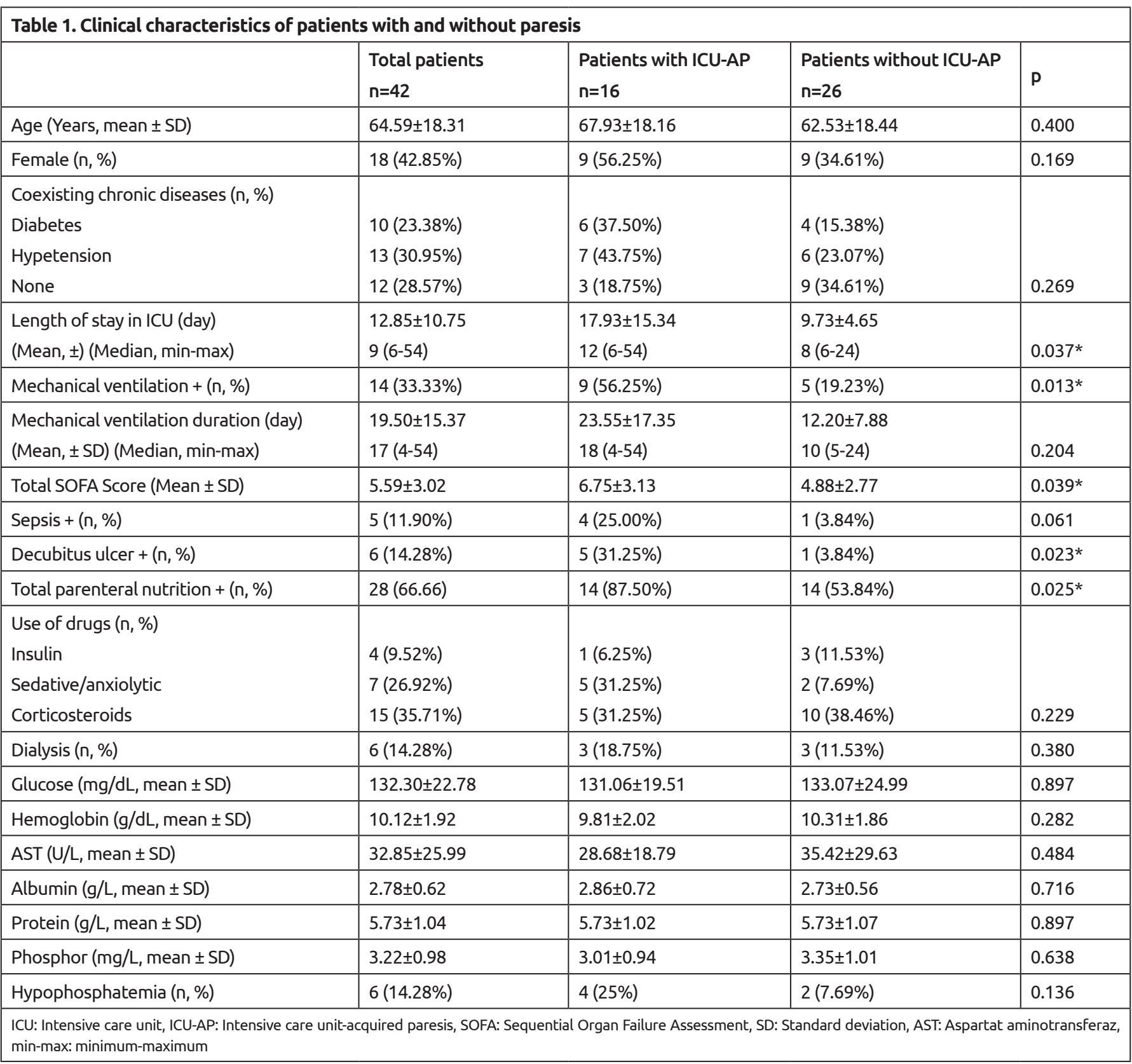

Total SOFA score, length of stay in ICU, mechanical ventilation rate, total parenteral nutrition and decubitis ulcer rate were higher in ICU-AP group. Factors influencing muscle weakness such as length of stay in ICU, mechanical ventilation, disease severity (SOFA score), decubitis ulcers was evaluated by univariate analyses and significant variables (SOFA score, total parenteral nutrition and mechanical ventilator) assessed by binary logistic regression analyses. Our results indicated that there was a significant association between only mechanical ventilation and ICU-AP (Table 3).

\section{Discussion}

Neuromyopathy in ICU patients is associated with worse discharge outcomes and deterioration in daily living activities. ICU-AP awareness is increasing day by day worldwide. In this study our purpose was to investigate the ICU-AP rates and risk factors for paresis in our conscious ICU patients. Our results support that ICU-AP frequency was more than one third of conscious patients and the most important factor for ICU paresis was mechanical ventilator. 


\begin{tabular}{|c|c|c|c|c|}
\hline & $\begin{array}{l}\text { Total patients } \\
\mathrm{n}=42\end{array}$ & $\begin{array}{l}\text { Patients with ICU-AP } \\
\mathrm{n}=16\end{array}$ & $\begin{array}{l}\text { Patients without ICU-AP } \\
n=26\end{array}$ & $\mathrm{p}$ \\
\hline $\begin{array}{l}\text { Handgrip strength } \\
\text { (kg, mean, } \pm \mathrm{SD} \text { ) } \\
\text { (Median, min-max) }\end{array}$ & $\begin{array}{l}15.41 \pm 11.40 \\
15(1-42.5)\end{array}$ & $\begin{array}{l}7.40 \pm 10.49 \\
2.50(1-15)\end{array}$ & $\begin{array}{l}20.34 \pm 8.99 \\
18(5-42.5) \\
\end{array}$ & $<0.001^{*}$ \\
\hline $\begin{array}{l}\text { Finger pinch strength } \\
\text { (kg, mean, } \pm \mathrm{SD} \text { ) } \\
\text { (Median, min-max) }\end{array}$ & $\begin{array}{l}3.99 \pm 2.65 \\
4(0.50-9.50)\end{array}$ & $\begin{array}{l}1.81 \pm 2.32 \\
0.50(1-3)\end{array}$ & $\begin{array}{l}5.33 \pm 1.89 \\
5.50(2.50-9.50)\end{array}$ & $<0.001^{*}$ \\
\hline $\begin{array}{l}\text { Mobilization level }(n, \%) \\
\text { Non-mobilized } \\
\text { Sitting at the edge of the bed } \\
\text { Transferring from bed to chair } \\
\text { Walking }\end{array}$ & $\begin{array}{l}13(30.95 \%) \\
14(33.33 \%) \\
6(14.28 \%) \\
9(21.42 \%)\end{array}$ & $\begin{array}{l}11(68.75 \%) \\
2(12.50 \%) \\
3(18.75 \%) \\
0\end{array}$ & $\begin{array}{l}2(7.69 \%) \\
12(41.15 \%) \\
3(11.61 \%) \\
9(34.61 \%)\end{array}$ & $<0.001 *$ \\
\hline $\begin{array}{l}\text { Discharge status }(n, \%) \\
\text { Exitus } \\
\text { Another clinic } \\
\text { Palliative care } \\
\text { Home }\end{array}$ & $\begin{array}{l}2(4.76 \%) \\
24(57.14 \%) \\
7(16.66 \%) \\
9(21.42 \%)\end{array}$ & $\begin{array}{l}1(6.25 \%) \\
10(62.5 \%) \\
4(25.00 \%) \\
1(6.25 \%)\end{array}$ & $\begin{array}{l}1(3.84 \%) \\
14(53.84 \%) \\
3(11.53 \%) \\
8(30.76 \%)\end{array}$ & 0.250 \\
\hline
\end{tabular}

\begin{tabular}{|c|c|c|c|c|c|c|c|}
\hline \multicolumn{2}{|l|}{ ICU-AP } & \multirow{2}{*}{$\begin{array}{l}\text { B } \\
-1.099\end{array}$} & \multirow{2}{*}{\begin{tabular}{|l|} 
SE \\
0.436
\end{tabular}} & \multirow{2}{*}{$\begin{array}{l}\mathbf{p} \\
0.012\end{array}$} & \multirow[t]{2}{*}{$\operatorname{Exp}(B)$} & \multicolumn{2}{|l|}{$95 \% \mathrm{Cl}$} \\
\hline MRC scale sore $<48$ & Constant & & & & & & \\
\hline & SOFA score & 0.111 & 0.135 & 0.408 & 0.895 & 0.687 & 1.165 \\
\hline & Total parenteral nutrition & 1.333 & 0.903 & 0.140 & 0.264 & 0.045 & 1.547 \\
\hline & Mechanical ventilation & 1.686 & 0.708 & $0.017^{*}$ & 0.185 & 0.046 & 0.742 \\
\hline
\end{tabular}

ICU-AP frequency has reported between 25\% and $55 \%$ in literature $(1,2,10-14)$. Cramer mentioned that change in electrophysiological findings (sudden decrease in compound muscle action potential amplitude) indicating the development of CINM was monitored in higher than 65\% of patients in one study (15). Although there is not a clear comparison, studies analyzing similar patient population found clinical ICU-AP in $25.3 \%$ while electrophysiological abnormalities was detected in $58 \%$ of the patients $(16,17)$. Electroneuromyography also guides to evaluate weakness in altered-state of consciousness patients while muscle strength examination for MRC scale needs cooperative patients. On the other hand attainability of electrophysiological equipment and experienced clinicians can be considered as the limitations for this method, and therefore clinic muscle strength examination is still important for assessments. In this study we found $38.09 \%$ of the awake and conscious patients had ICU-AP according to MRC scale score. Our rate is similar to literature; furthermore studies with electrophysiological assessments may indicate higher paresis rates.

Neuromuscular dysfunctions in ICU patients are combined with worse functional outcomes (10).

Handgrip strength is identified as an advantageous test for muscle weakness, was found correlated with sarcopenia and it has been used for ICU-AP in different studies $(1,16,18,19)$. Although expected handgrip strength cutoff value for hospitalized patients can be less than age and sex 
matched healthy controls different factors affect this test in critically ill patients and Ali et al. (16) indicated that a force value for $<11 \mathrm{~kg}$ for males and $<7 \mathrm{~kg}$ for females is adequate for ICU-AP description. Handgrip strength test with Jamar dynamometer appears to be a shorter test as compared to general muscle strength examination, it does not need a different positioning for each muscle group, and additionally it shows results in a more objective numeric scale. In our study we were able to perform handgrip strength test in all of the patients who had completed general muscle strength test. Differently from other studies we performed finger pinch test for all of the participants and our results demonstrated that there was a meaningful association between MRC scale, handgrip strength and finger pinch strength. Our results support that that weakness should be taken into account not only in the proximal but also in the distal muscle groups in ICU-AP patients in addition to this finger pinch and handgrip strength tests are useful to assess critically ill patients.

Prolonged mechanical ventilation, increased mortality rates, functional disabilities after discharge, and higher costs are identified as worse outcomes for patients with ICU-AP (20). Due to these reasons, early diagnosis of ICU-AP may provide early rehabilitation opportunity to improve the functionality ant to decrease the unfavorable outcomes. Nguyen The and Nguyen Huu (10) found longer duration of stay in ICU and in hospital and higher mortality rates in patients with ICU-AP. As a matter of fact, there is a complicated relationship between ICU-AP, underlying disease, severity of critical illness, development of organ failure over time, functional outcomes, and mortality rates. Peñuelas et al. (20) who studied to clarify this contradiction reported that ICU-AP influences ICU mortality rates. Our patients with ICU-AP demonstrated worse functional outcomes and lower discharge (to home) rate in accordance with literature. Patients with ICU-AP showed very low mobilization rates, $68.75 \%$ of the ICU-AP group could not be mobilized at all.

ICU-AP associated risk factors were determined as multiple organ failure, persistent systemic inflammation, sepsis, severity of illness, hyperglycemia, duration of ICU stay, parenteral nutrition, and red blood cell transfusion. Several medications such as vasopressors, catecholamines, neuromuscular blockers and corticosteroids have been offered as risk factors for ICU-AP, however conflicting results have been published concerning this issue (1-5,20). In our analysis we found longer duration of stay in ICU, higher mechanical ventilation rates and higher disease severity (SOFA score) in patients with ICU-AP. Binary logistic regression analyses indicated that mechanical ventilation was a risk factor for paresis. Unlike many studies in the literature, only the patients in the mechanical ventilator were not evaluated in our study and consequently our results indicated that patients who are not dependent on mechanical ventilation may also develop ICU-AP and mechanical ventilator is a risk factor for paresis $(10,16,20)$.

\section{Study Limitations}

Limitation of this study was small patient population. This is due to the fact that this is a local, single-centered study and a few numbers of patients was cooperative with strength examination in ICU. Our preliminary results may be beneficial for the studies concerning about weakness and rehabilitation in the ICU in larger patient groups.

\section{Conclusion}

In conclusion ICU-AP is a common problem in critically ill patients and influences outcomes of patients. Patients without mechanical ventilation may develop ICU-AP and mechanical ventilation is an independent risk factor for paresis. Handgrip and finger pinch strength assessments are in accordance with general muscle strength examination and they are beneficial tests for ICU-AP diagnosis.

\section{Ethics}

Ethics Committee Approval: Our study protocol was approved by the Ankara Numune Training and Research Hospital Clinical Researches Local Ethics Committee with the decision no: 1314-2017, approval date: 29.03.2017.

Informed Consent: Written informed consent was obtained from all the patients or patients' first degree relatives.

Peer-review: Externally and internally peer-reviewed.

\section{Authorship Contributions}

Concept: F.G.Y., A.Ç.U., N.M.M., Ö.B.S., I.Ö.T., H.B., Design: F.G.Y., A.Ç.U., N.M.M., Ö.B.S., I.Ö.T., H.B., Data Collection or Processing: F.G.Y., A.Ç.U., N.M.M., Ö.B.S., Analysis or Interpretation: I.Ö.T., H.B., Literature Search: F.G.Y., A.Ç.U., N.M.M., Ö.B.S., I.Ö.T., H.B., Writing: A.Ç.U., F.G.Y.

Conflict of Interest: No conflict of interest was declared by the authors.

Financial Disclosure: The authors declared that this study received no financial support. 


\section{References}

1. Parsons EC, Kross EK, Ali NA, Vandevusse LK, Caldwell ES, Watkins $T R$, et al. Red blood cell transfusion is associated with decreased in-hospital muscle strength among critically ill patients requiring mechanical ventilation. J Crit Care 2013;28:1079-85.

2. Routsi C, Gerovasili V, Vasileiadis I, Karatzanos E, Pitsolis T, Tripodaki E, et al. Electrical muscle stimulation prevents critical illness polyneuromyopathy: a randomized parallel intervention trial. Crit Care 2010;14:R74.

3. Witteveen E, Wieske L, de Beer FM, Juffermans NP, Verhamme C, Schultz MJ, et al. No association between systemic complement activation and intensive care unit-acquired weakness. Ann Transl Med 2018;6:115

4. De Jonghe B, Sharshar T, Lefaucheur JP, Authier FJ, Durand-Zaleski I, Boussarsar $\mathrm{M}$, et al. Paresis acquired in the intensive care unit: a prospective multicenter study. JAMA 2002;288:2859-67.

5. Hermans G, De Jonghe B, Bruyninckx $F$, Van den Berghe $G$. Interventions for preventing critical illness polyneuropathy and critical illness myopathy. Cochrane Database Syst Rev 2014:CD006832.

6. Apostolakis E, Papakonstantinou NA, Baikoussis NG, Papadopoulos G. Intensive care unit-related generalized neuromuscular weakness due to critical illness polyneuropathy/myopathy in critically ill patients. J Anesth 2015:29:112-21.
7. Hansen-Flaschen J, Cowen J, Polomano $\mathrm{RC}$. Beyond the Ramsay scale: need for a validated measure of sedating drug efficacy in the intensive care unit. Crit Care Med 1994;22:732-3.

8. Vincent JL, de Mendonça A, Cantraine F, Moreno R, Takala J, Suter PM, et al. Use of the SOFA score to assess the incidence of organ dysfunction/failure in intensive care units: results of a multicenter, prospective study. Working group on "sepsis-related problems" of the European Society of Intensive Care Medicine. Crit Care Med 1998;26:1793800.

9. Barreiro E. Models of disuse muscle atrophy: therapeutic implications in critically ill patients. Ann Transl Med 2018;6:29.

10. Nguyen The L, Nguyen Huu C. Critical illness polyneuropathy and myopathy in a rural area in Vietnam. J Neurol Sci 2015:357:276-81.

11. Shechtman O, Gestewitz L, Kimble C.Reliability and validity of the DynEx dynamometer. J Hand Ther 2005;18:33947.

12. Ali NA, O'Brien JM Jr, Hoffmann SP, Phillips G, Garland A, Finley JC, et al. Acquired weakness, handgrip strength, and mortality in critically ill patients. Am J Respir Crit Care Med 2008;178:261-8.

13. Thabet Mahmoud A, Tawfik MAM, Abd El Naby SA, Abo El Fotoh WMM, Saleh NY, Abd El Hady NMS. Neurophysiological study of critical illness polyneuropathy and myopathy in mechanically ventilated children; additional aspects in paediatric critical illness comorbidities. Eur J Neurol 2018;25:991-e76.

14. Sánchez Solana L, Goñi Bilbao I, Ruiz García P, Díaz Agea JL, Leal Costa C. Acquired neuromuscular dysfunction in the intensive care unit. Enferm Intensiva 2018;29:128-37.

15. Kramer CL. Intensive Care Unit-Acquired Weakness. Neurol Clin 2017;35:723-36.

16. Ali NA, O'Brien JM Jr, Hoffmann SP, Phillips G, Garland A, Finley JC, et al. Acquired weakness, handgrip strength, and mortality in critically ill patients. Am J Respir Crit Care Med 2008;178:261-8.

17. De Jonghe B, Cook D, Sharshar T, Lefaucheur JP, Carlet J, Outin H. Acquired neuromuscular disorders in critically ill patients: a systematic review. Groupe de Reflexion et d'Etude sur les Neuromyopathies En Reanimation. Intensive Care Med 1998;24:1242-50.

18. Wigodski $S$, Carrasco F, Bunout D, Barrera G, Hirsch S, de la Maza MP. Sarcopenia: The need to establish different cutoff points of fat-free mass for the Chilean population. Nutrition 2019;57:217-24.

19. Dietrich C, Cardoso JR, Vargas F, Sanchez EC, Dutra FH, Moreira C, et al. Functional ability in younger and older elderlies after discharge from the intensive care unit. A prospective cohort. Rev Bras Ter Intensiva 2017;29:293-302.

20. Peñuelas O, Muriel A, Frutos-Vivar F, Fan E, Raymondos K, Rios F, et al. Prediction and Outcome of Intensive Care UnitAcquired Paresis. J Intensive Care Med 2018;33:16-28. 